\title{
Preventive effects of Salvia officinalis leaf extract on insulin resistance and inflammation in a model of high fat diet-induced obesity in mice that responds to rosiglitazone
}

\author{
Mohamed R. Ben Khedher ${ }^{1}$ ， Mohamed Hammami ${ }^{1}$ ， Jonathan R. S. Arch ${ }^{2}$ ， David C. Hislop ${ }^{2}$, Dominic Eze ${ }^{3}$, \\ Edward T. Wargent ${ }^{2}$, Małgorzata A. Kępczyńska ${ }^{2}$, Mohamed S. Zaibi ${ }^{\text {Corresp. } 2}$ \\ ${ }^{1}$ Biochemistry Department, Research Laboratory 'Nutrition - Functional Food \& Vascular Health', Faculty of Medicine, University of Monastir, Monastir, \\ Tunisia \\ 2 Buckingham Institute for Translational Medicine (BITM), Clore Laboratory, University of Buckingham, Buckingham, United Kingdom \\ 3 Medical School, University of Buckingham, Buckingham, United Kingdom \\ Corresponding Author: Mohamed S. Zaibi \\ Email address: mohamed.zaibi@buckingham.ac.uk
}

Background: Salvia officinalis (sage) is a native plant to the Mediterranean region and has been used for a long time in traditional medicine for various diseases. We investigated possible anti-diabetic, antiinflammatory and anti-obesity effects of sage methanol (MetOH) extract in a nutritional mouse model of obesity, inflammation and insulin resistance, as well as its effects on lipolysis and lipogenesis in 3T3-L1 cells.

Methods: Diet-induced obese (DIO) mice were treated for 5 weeks with sage methanol extract (100 and $400 \mathrm{mg} \cdot \mathrm{kg}^{-1} /$ day. bid), or rosiglitazone (3 mg. $\mathrm{kg}^{-1} /$ day. bid), as a positive control. Energy expenditure, food intake, body weight, fat mass, liver glycogen and lipid content were evaluated. Blood glucose, and plasma levels of insulin, lipids leptin and pro- and anti-inflammatory cytokines were measured throughout the experiment. The effects of sage MetOH extract on lipolysis and lipogenesis were tested in vitro in 3T3-L1 cells.

Results: After two weeks of treatment, the lower dose of sage MetOH extract decreased blood glucose and plasma insulin levels during an oral glucose tolerance test (OGTT). An insulin tolerance test (ITT), performed at day 29 confirmed that sage improved insulin sensitivity. Groups treated with low dose sage and rosiglitazone showed very similar effects on OGTT and ITT. Sage also improved HOMA-IR, triglycerides and NEFA. Treatment with the low dose increased the plasma levels of the antiinflammatory cytokines IL-2, IL-4 and IL-10 and reduced the plasma level of the pro-inflammatory cytokines IL-12, TNF- $\alpha$, and KC/GRO. The GC analysis revealed the presence of two PPARs agonist in sage $\mathrm{MetOH}$ extract. In vitro, the extract reduced in a dose-related manner the accumulation of lipid droplets; however no effect on lipolysis was observed.

Conclusions: Sage MetOH extract at low dose exhibits similar effects to rosiglitazone. It improves insulin sensitivity, inhibits lipogenesis in adipocytes and reduces inflammation as judged by plasma cytokines. Sage presents an alternative to pharmaceuticals for the treatment of diabetes and associated inflammation. 
1 Title: Preventive effects of Salvia officinalis leaf extract on insulin resistance 2 and inflammation in a model of high fat diet-induced obesity in mice that responds to rosiglitazone

4 Mohamed R. Ben Khedher ${ }^{1}$, Mohamed Hammami ${ }^{1}$, Jonathan R.S. Arch ${ }^{2}$, David C. Hislop ${ }^{2}$, 5 Dominic Eze ${ }^{3}$, Edward T. Wargent ${ }^{2}$, Małgorzata A. Kępczyńska² and Mohamed S. Zaïbi ${ }^{2}$,

$6{ }^{1}$ Biochemistry Department, Research Laboratory 'Nutrition - Functional Food \& Vascular

7 Health'. Faculty of Medicine, University of Monastir, Monastir. Tunisia.

8 2Buckingham Institute for Translational Medicine (BITM), Clore Laboratory, University of

9 Buckingham, Buckingham. United Kingdom.

$10{ }^{3}$ Medical School, University of Buckingham, Buckingham. United Kingdom.

11 *Corresponding author

12 Dr. Mohamed S. Zaïbi

13 Buckingham Institute for Translational Medicine (BITM)

14 Clore Laboratory, University of Buckingham

15 Buckingham. United Kingdom

16 Email: mohamed.zaibi@buckingham.ac.uk

17 Phone: +441280820370 . Fax: +44 1280822245. 
18 Abstract

19 Background Salvia officinalis (sage) is a native plant to the Mediterranean region and has been used for a long time in traditional medicine for various diseases. We investigated possible antidiabetic, anti-inflammatory and anti-obesity effects of sage methanol (MetOH) extract in a nutritional mouse model of obesity, inflammation and insulin resistance, as well as its effects on lipolysis and lipogenesis in 3T3-L1 cells.

24 Methods Diet-induced obese (DIO) mice were treated for 5 weeks with sage methanol extract (100 and $400 \mathrm{mg} \cdot \mathrm{kg}^{-1} / \mathrm{day}$. bid), or rosiglitazone (3 mg.kg-1/day. bid), as a positive control. Energy expenditure, food intake, body weight, fat mass, liver glycogen and lipid content were evaluated. Blood glucose, and plasma levels of insulin, lipids leptin and pro- and antiinflammatory cytokines were measured throughout the experiment. The effects of sage MetOH extract on lipolysis and lipogenesis were tested in vitro in 3T3-L1 cells.

Results After two weeks of treatment, the lower dose of sage MetOH extract decreased blood glucose and plasma insulin levels during an oral glucose tolerance test (OGTT). An insulin tolerance test (ITT), performed at day 29 confirmed that sage improved insulin sensitivity.

33 Groups treated with low dose sage and rosiglitazone showed very similar effects on OGTT and ITT. Sage also improved HOMA-IR, triglycerides and NEFA. Treatment with the low dose

35 increased the plasma levels of the anti-inflammatory cytokines IL-2, IL-4 and IL-10 and reduced 36 the plasma level of the pro-inflammatory cytokines IL-12, TNF- $\alpha$, and KC/GRO.

37 The GC analysis revealed the presence of two PPARs agonist in sage MetOH extract. In vitro, the extract reduced in a dose-related manner the accumulation of lipid droplets; however no effect on lipolysis was observed. 
40 Conclusions Sage MetOH extract at low dose exhibits similar effects to rosiglitazone. It

41 improves insulin sensitivity, inhibits lipogenesis in adipocytes and reduces inflammation as

42 judged by plasma cytokines. Sage presents an alternative to pharmaceuticals for the treatment of

43 diabetes and associated inflammation.

\section{Introduction}

45 In the recent decades, there has been renewed interest in traditional and alternative medicine and

46 thousands of potential medicinal plants have been screened to identify bio-active lead

47 components. Salvia officinalis (Sage) has been extensively used as a medicinal plant in treating

48 several diseases and recent studies have shown promising activity in treating cancer (Shahneh et

49 al., 2013), heart disease, dementia and obesity (Hamidpour et al., 2014).

50 Studies have suggested that sage extracts enhance glycemic balance in normal and

51 diabetic animals. Alarcon-Aguilar et al. (2002) showed that a water ethanolic extract from $S$.

52 officinalis injected intraperitoneally had hypoglycemic effects in fasted normoglycemic mice and

53 in fasted alloxan-induced mildly diabetic mice. In addition, Eidi et al. (2005) showed that sage

54 methanolic $(\mathrm{MetOH})$ extract given intraperitoneally reduced significantly serum glucose in

55 fasted streptozotocin (STZ)-induced diabetic rats without changes in plasma insulin levels. In

56 another study, sage ethanolic extract significantly decreased serum glucose, triglycerides and

57 total cholesterol, whereas it increased serum insulin levels in STZ-treated diabetic rats as

58 compared with control diabetic rats (Eidi \& Eidi, 2009). Sage essential oil tested in normal and

59 in alloxan-induced diabetic rats improved glycemia (Baricevic \& Bartol, 2000) and increased the

60 response of the hepatocytes to insulin in normal animals but not in hepatocytes isolated from 
61 STZ diabetic rat (Lima et al., 2006). Sage is reported to elicit antidiabetic effects largely due to

62

63 activation of peroxisome proliferator-activated receptors (PPARs) (Christensen et al., 2010). Most of the studies described above have investigated the anti-diabetic effects of sage in alloxan- or streptozotocin-induced diabetic animals. However, the effects of sage on insulin sensitivity and glucose tolerance in a nutritional animal model of obesity and insulin resistance have not been described before. The aim of our present study is to assess the potential antiinflammatory, anti-obesity, and anti-diabetic effects of low and high doses of a MetOH extract of S. officinalis leaves, in a high fat diet-induced obesity mice model, which is a nutritional animal model of obesity associated with dyslipidemia, inflammation and insulin resistance and to appraise the effect of sage MetOH extract in 3T3-L1 cells on lipolysis and lipogenesis.

\section{Materials and Methods}

\section{Chemicals and reagents}

Methanol (Sigma-Aldrich, Germany), dimethyl sulfoxide (DMSO, Biotech grade, 99.98\%, Sigma-Aldrich), Dulbecco's modified Eagle's medium (DMEM), $0.25 \%$ trypsin-EDTA (1X), fetal bovine serum (FBS), streptomycin/penicillin (Gibco BRL, Life Technologies, USA), bovine insulin (Sigma I-5500), dexamethasone, (Sigma D-4902), 3-isobutyl-1 methylxanthine (IBMX; Sigma I-7018), rosiglitazone maleate (SRP0135r, Sequoia RP, UK).

\section{Preparation of plant material}

Leaves of Salvia officinalis (Lamiaceae Plant family) were collected from the open field botanic garden of the Higher Institute of Agronomy, University of Sousse, Tunisia and were identified by Pr. Rabiaa Hawéla at the cited institute. Voucher specimens were deposited at the Faculty of 
82 Medicine of Monastir, Tunisia, and referenced as SO011. Air dried leaves were submitted to 83 extraction with $80 \% \mathrm{MetOH}$ solution in a Soxhlet apparatus for $24 \mathrm{~h}$. The solvent was then

84 filtered and evaporated by Rotavapor at $55^{\circ} \mathrm{C}$. The recuperated aqueous portion was lyophilized 85 and stored at $-20^{\circ} \mathrm{C}$, for fatty acids (FAs) analysis, and for in vitro and in vivo experiments.

\section{Fatty acid methylation and analysis}

87 Fatty acid (FA) extraction was performed using a modified method of Folch et al. (1957). Heptadecanoic acid (C17:0) was used as an internal standard in order to quantify FAs. Total FAs were converted into their methyl esters using $\mathrm{MetOH} / \mathrm{H}_{2} \mathrm{SO}_{4}$ at 2.5\%. FA methyl esters (FAMEs) were analyzed using a Hewlett Packard 5890 IIGC (Agilent Technologies, USA) equipped with Flame Ionization Detector (FID) and Supelcowax ${ }^{\mathrm{TM}} 10$ capillary column $(30 \mathrm{~m} \times 0.32 \mathrm{~mm}$, i.d., $0.25 \mu \mathrm{m}$ film thickness) with a stationary phase made of polyethylene glycol. FAMEs were identified by comparing each sample with a standard FAME reference mixture. FA acid peak areas were calculated using HP ChemStation software, quantified according to their percentage area and expressed in $\mu \mathrm{g} / \mathrm{g}$ of dry plant material.

\section{HPLC Phenolic compounds analysis in sage methanol extract}

HPLC analysis was carried out as reported by Mhamdi et al. (2009). Separation was performed using a Hewlett-Packard liquid chromatographic system (Waldbronn) equipped with a Rheodyne Model 7125 injector (Cotati, CA, USA), a HP 1100 pump system and an HP 1040M detector (diode array detection system, DAD). The column was an XDB-C18 (250 mm × $4.6 \mathrm{~mm}$ I.D., 5

$101 \mu \mathrm{m}$ particle size). The mobile phase consisted of acetonitrile/acidified water (solvent A) with 102 $0.2 \%$ sulfuric acid (solvent B). The selected gradient was as follows: $15 \% \mathrm{~A} / 85 \% \mathrm{~B}, 0-12 \mathrm{~min}$; 
103

104

105

106

107

108

109

110

111

112

113

114

115

116

117

118

119

120

121

122

$40 \% \mathrm{~A} / 60 \% \mathrm{~B}, 12-14 \mathrm{~min} ; 60 \% \mathrm{~A} / 40 \% \mathrm{~B}, 14-18 \mathrm{~min} ; 80 \% \mathrm{~A} / 20 \% \mathrm{~B}, 18-20 \mathrm{~min} ; 90 \% \mathrm{~A} / 10 \%$

B, 20-24 min; 100\% A, 24-28 min (Bourgou et al., 2008). The flow rate was maintained at 2 $\mathrm{mL} / \mathrm{min}$ and a final volume of $20 \mu \mathrm{L}$ was injected. The data were stored and processed by an HPLC Chemstation (Dos Series, Hewlett-Packard) and identification of compounds was carried out by comparison of their retention time with respect to pure standards analyzed under the same operating conditions.

\section{In vitro experiment}

\section{Cell culture}

3T3-L1 cell line was purchased from Sigma, UK (Ref: 86052701). After a few passages in the growth medium containing basal Dulbecco's Modified Eagle's Medium - high glucose, (DMEM) supplemented with fetal bovine serum (FBS) 10\%, and Penicillin-Streptomycin (S/P) $100 \mathrm{IU} / \mathrm{ml}$, the cells were seeded in 24 well plates in the growth medium until they reached confluency. To initiate pre-adipocytes differentiation into adipocyte-like cells, the cells were incubated in the differentiation medium (day 0) containing 10\% FBS supplemented DMEM with $\mathrm{S} / \mathrm{P}, 5 \mu \mathrm{g} / \mathrm{ml}$ bovine insulin, $0.5 \mathrm{mM}$ IBMX and $0.5 \mu \mathrm{M}$ dexamethasone. On day 3 , the differentiation medium was replaced by the nutrition medium $(10 \%$ FBS supplemented DMEM with $\mathrm{S} / \mathrm{P}$ and $5.10^{-3} \mathrm{mg} / \mathrm{ml}$ bovine insulin). By day 7-10, mature adipocytes were obtained.

\section{Glycerol release}

After complete differentiation of pre-adipocytes, the nutrition media was removed and mature 3T3-L1 cells were incubated for 90 minutes at $37^{\circ} \mathrm{C}$, in $0.5 \mathrm{ml}$ of DMEM/ Ham's F-12[1:1], 
123 containing $0.1 \%$ of BSA and with or without $0.2,1,5,25$ and $50 \mu \mathrm{g} / \mathrm{ml}$ of sage MetOH extract

124 dissolved in $0.01 \%$ DMSO. The glycerol released into the medium was quantified by using a 125 colorimetric method (Glycerol kit, GY105, Randox). Optical density was measured at $520 \mathrm{~nm}$

126 using SpectraMax 96- well plate reader.and results expressed in $\mu \mathrm{mol} / \mathrm{mg}$ of cell protein.

\section{Lipid droplets accumulation}

128 To evaluate the effects of sage extract on lipid droplets accumulation, the cells were treated with

129 the plant extract dissolved in $0.01 \%$ DMSO at the following concentrations: $0,0.2,1,5,25$ and

$13050 \mu \mathrm{g} / \mathrm{ml}$. The extract was added to the differentiation medium, the nutrition medium, or both

131 media. Lipid droplets accumulation was assessed by staining lipids with Oil red O as employed

132 by Ramírez-Zacarías et al. (1992). The absorbance of the eluted dye was measured at $500 \mathrm{~nm}$,

\section{In vivo experiment}

134 Animal model

32 male mice (C57B16) aged 6-7 weeks on arrival (Source: Harlan UK) were fed on a high fat

136 diet (60\% fat by energy value; cat \#D12492, Research Diets, US. Diet composition is described

137 in Table 1) for 9 weeks before treatment. The mice were housed at $25 \pm 1^{\circ} \mathrm{C}, 40 \%$ to $60 \%$ air

138 humidity and $12 \mathrm{~h}$ light/dark cycle in groups of 4 per cage with free access to high fat diet (HFD)

139 and tap water. Animal experiments were conducted in accordance with ethical procedures and

140 policies approved by the UK Government Animal Act 1986 (Scientific procedures) Project

141 Licence (PPL 70/7189), entitled "Identifying diabetes, obesity and metabolic diseases

142 therapeutics", and Animal Welfare and Ethical Review Board (AWERB) of the University of

143 Buckingham, UK. 
After 9 weeks of HFD feeding, mice were fasted for 5h from 09:00 and fasting blood 145 glucose and plasma insulin were measured. 31 mice exhibited plasma insulin levels over 250

146 pmol.1 $1^{-1}$, one mouse was excluded because of normal plasma insulin level (less than 150 pmol.1 $^{-}$

$147^{1}$ ). Mice were then allocated into four groups with approximately the same body weight, plasma

148 insulin and blood glucose levels. Seven mice in group A, eight mice in group B, eight mice in 149 group C and eight mice in group D.

$150 \quad$ Animals were treated as described below for 5 weeks:

151 A: Control (water, $10 \mathrm{ml} \cdot \mathrm{kg}^{-1} /$ day. bid)

152 B: Sage extract (100 mg.kg-1/day. bid)

153 C: Sage extract (400 mg.kg-1/day. bid)

154 D: Rosiglitazone (3 $\mathrm{mg} \mathrm{kg}^{-1} /$ day. bid)

155 The animals were dosed twice per day at 9:00 am and 5:00 pm.

\section{Analysis}

\section{Biochemical analysis}

Blood samples were centrifuged at $5000 \mathrm{~g}$ for $6 \mathrm{~min}$ and plasma were collected into 96-well plates and stored at $-20^{\circ} \mathrm{C}$ until assayed. The tested biochemical parameters were: insulin (Ultra Sensitive Mouse Insulin ELISA kit, Catalog \#: 90080, Crystal Chem), leptin (Catalog \#: 90030, 161 Chrystal Chem), total cholesterol (Randox Laboratories, ref: CH200), triglycerides (Randox 162 laboratories, ref: TR1697), high density lipoprotein cholesterol (HDL-C) (Trinity Biotech, ref: 163 354LB). Blood glucose was measured using a glucose oxidase reagent kit (Gluc-PAP, GL2623, 164 Randox). All parameters were analyzed automatically using SpectraMax 250 and SoftMax Pro 165 software. 
166

167

168

169

170

171

172

173

174

175

176

177

178

179

180

181

182 183

184

185

\section{Body composition}

Lean and fat mass were measured by Nuclear Magnetic Resonance (NMR), using the minispec LF 90 II device (Bruker UK Limited). The different types of tissue were identified according to their density by comparison with a calibrated standard. Dedicated software is used to quantify amounts of lean and fat.

\section{Energy expenditure}

After 35 days of treatment, energy expenditure was measured by indirect calorimetry as reported by Stocker et al. (2007). Energy expenditure was evaluated based on the equation of Weir using customized software (Arch et al., 2006).

\section{Oral Glucose Tolerance Test (OGTT) and Insulin Tolerance Test (ITT)}

OGTT and ITT were performed respectively at 2 and 4 weeks following the start of treatment with the plant extract. Mice were fasted for 5 hours before the OGTT and ITT. We and others routinely use a fast of about this length. Fasting mice for 5-6 h instead of overnight might offer a better comparison to humans. Indeed, after having reviewed a number of studies, Jensen et al. (2013) concluded that because the mouse has a nocturnal circadian rhythm (two-thirds of total food intake are consumed during the night) and a higher metabolic rate, therefore, a 16-18h fast affects metabolism far more in mice than in humans. Overnight fast is a routine event in humans, but not in mice.

For OGTT, 5 hour-fasted mice received by oral gavage a glucose solution (in distilled water) 2.5 $\mathrm{g} / 10 \mathrm{ml} \cdot \mathrm{kg}^{-1}$, and blood samples $(10 \mu \mathrm{l})$ were collected by incision from the tail for glucose 
186 measurement at 30 and $0 \mathrm{~min}$ before, and, 30, 60, 120 and $180 \mathrm{~min}$ after the glucose load.

187 Plasma insulin levels were measured at -30 and $+30 \mathrm{~min}$. Blood glucose levels were measured

188 using glucose oxidase reagent. For the ITT, $5 \mathrm{~h}$-fasted mice received $0.75 \mathrm{IU} / \mathrm{kg}$ of insulin

189 solution (Actrapid. HM, Novo Nordisk, Denmark) by intraperitoneal injection, and blood 190 glucose was measured at just prior to the insulin injection, and at 10, 20, 30, 45, and 60 min 191 following the injection.

\section{Liver Triglycerides measurement}

193 About 150 to $300 \mathrm{mg}$ of liver samples were used to assess triglycerides content as described by 194 Harzallah et al. (2016). The reading was performed using the Randox triglycerides kit.

195

196 197

198

199

200

201

202

203

204

\section{Liver glycogen measurement}

The glycogen content was determined according to Deng et al. (2016). The concentration was expressed in mmol of glycosyl residues/g tissue.

\section{Inflammatory cytokines measurement}

The pro- and anti-inflammatory cytokines interleukin IL-1 $\beta$, IL-2, IL-4, IL-5, IL-6, IL-10, IL12p70, tumor necrosis factor- $\alpha(\mathrm{TNF}-\alpha)$, keratinocyte-derived chemoattractant/human growthregulated oncogene $(\mathrm{KC} / \mathrm{GRO})$ and interferon- $\gamma(\mathrm{IFN}-\gamma)$ were measured using Meso Scale multiplex assay kit (V-PLEX, Pro-inflammatory Panel 1 mouse kit, Ref: K15048D-1, USA). Optical density was read using an MSD instrument (SECTOR Imager 2400), and the data were analyzed using Proprietary Meso Scale software. 
206 Statistical analysis was carried out by one way ANOVA followed by Dunnett's Multiple

207 Comparison Test and Student t-test using GraphPad Prism software version 5.0. All results are

208 presented as means \pm S.E.M. Statistical significance is indicated by $* \mathrm{P}<0.05$, $* * \mathrm{P}<0.01$;

$209 * * * \mathrm{P}<0.001$

210 Results

211 Glycerol release in 3T3-L1 cells

212 The lipolytic effect of sage in 3T3-L1 cells was determined by measuring glycerol release (Fig.

213 1A). Compared to the untreated cells, no difference was observed in glycerol levels measured in

214 the medium of treated cells with the plant extract at $0.2,1,5,25$ or $50 \mu \mathrm{g} / \mathrm{ml}$.

\section{Lipid droplets accumulation}

216 When the cells were treated with sage extract during the differentiation or the nutrition step,

217 (Figs. 1B and 1C) there was a significant reduction in the lipid accumulation only in the cells 218 treated with highest two concentrations (25 and $50 \mu \mathrm{g} / \mathrm{ml}$ ). However, when sage extract was 219 added to both differentiation and nutrition media (Fig. 1D), there was an inhibitory effect on 220 lipid droplets accumulation even with the low sage concentration $(0.2$ and $1 \mu \mathrm{g} / \mathrm{ml})$ with an 221 overall concentration-dependant manner.

\section{Oral glucose tolerance test (OGTT) and insulin tolerance test (ITT)}

223 OGTT was performed after 14 days of treatment. There was no change in fasted blood glucose in

224 all treated groups, but 30 min following the glucose load, the blood glucose levels in mice treated 225 with high $(\mathrm{p}<0.05)$ and low $(\mathrm{p}<0.001)$ dose of sage extract, and mice treated with rosiglitazone 
$226(\mathrm{p}<0.001)$ were significantly lower, compared to the control group values (Fig. 2A). Moreover,

227 the low dose of sage extract exhibited a similar effect to that of rosiglitazone on blood glucose,

228 and tended to decrease fasting plasma insulin levels $(\mathrm{p}=0.08)$. Compared to the control mice,

229 the plasma insulin levels measured $30 \mathrm{~min}$ in response to glucose load, were significantly lower

230 in rosiglitazone treated group $(\mathrm{p}<0.001)$, and in low $(\mathrm{p}<0.01)$ and high dose $(\mathrm{p}<0.05)$ treated

231 groups (Fig. 2B).

232 After 3 weeks, there was no difference in 5 hours fasted blood glucose levels of sage or 233 rosiglitazone treated mice compared to control group (Fig. 3A). However, the treatment with 234 high and low dose sage, and rosiglitazone resulted in a significant reduction in fasted plasma 235 insulin levels (high dose sage: $698 \pm 132$ pmol.1 ${ }^{-1}, \mathrm{p}<0.05$; low dose sage: $491 \pm 50$ pmol.1 -1 $^{-1} \mathrm{p}<$ 2360.01 ; rosiglitazone: $284 \pm 36 \mathrm{pmol}^{-1} \mathrm{I}^{-1} \mathrm{p}<0.001$ ). Consequently, the insulin sensitivity index, as 237 represented by the Homeostasis Model Assessment of Insulin Resistance (HOMA-IR) was 238 respectively reduced by 39,60 and $78 \%$, indicating a marked improvement in insulin sensitivity 239 by both sage extract and rosiglitazone (Fig. 3B).

An ITT was carried out after 4 weeks of treatment. The fasted blood glucose levels were reduced in low dose sage and rosiglitazone groups compared to control $(\mathrm{p}<0.05$ and $\mathrm{p}<0.01$, respectively) (Fig. 3C). Both groups showed a significant drop in blood glucose levels 10 and 20 min following the insulin injection (Fig. 3C). Despite the lower blood glucose levels in response to insulin injection in high dose sage treated group, no statistical significance was observed.

245 Nevertheless, the ITT supported evidence from the OGTT that the sage extract improved insulin 246 sensitivity.

\section{Effect of treatment on biochemical parameters}


248 After 5 weeks of treatment, there was no change in fed plasma leptin, total cholesterol and HDL-

249 cholesterol levels (Figs. 4B-C-D). On the other hand, the low dose of sage extract significantly

250 decreased fed plasma insulin, triglycerides and NEFA levels (Figs. 4A-E-F). There was no

251 difference in liver triglycerides and glycogen contents between all groups.

252 Effect of treatment on food intake, on body weight gain and energy expenditure

253 Cumulative food intake after 34 days of treatment was reduced in group B (100 mg. $\left.\mathrm{kg}^{-1}\right)$ 254 compared to the other groups (Table 2). Moreover, a decline $(p=0.018)$ in cumulative 255 bodyweight change was observed for the same group compared to the control group (Table 2).

256 This reduction in body weight in group $B$, could be explained by a decrease $(p=0.011)$ in fat

257 mass without any changes in lean mass (Table 2). Energy expenditure was measured for $24 \mathrm{~h}$ 258 after 35 days of treatment. There were no significant effects of treatment on expenditure per 259 animal or relative to body weight over the whole 24 hours or during the light or dark phases (data 260 not shown).

\section{Pro- and anti-inflammatory cytokines}

262 To investigate a potential anti-inflammatory effect of sage, plasma levels of a panel of pro- and 263 anti-inflammatory cytokines were measured. Compared to the control group, there was an 264 increase in the anti-inflammatory cytokines IL2, IL-4 and L-10 $(\mathrm{p}=0.003, \mathrm{p}=0.036$ and $\mathrm{p}=$ 265 0.006; respectively) (Fig. 5A), and a decrease in pro-inflammatory cytokines TNF- $\alpha$, KC/GRO 266 and IL-12 ( $\mathrm{p}=0.030, \mathrm{p}=0.004$ and $\mathrm{p}=0.034$; respectively), moreover the sage extract tend to 267 reduce as well the plasma levels of IL-1 $\beta$ (Fig. 5B). 


\section{Fatty acids composition of Sage MetOH extract}

269 As displayed in Fig. 6, the sage MetOH extract chromatographic analysis allowed the

270 identification of different FAs classes. The main FAs identified were: $\gamma$-linolenic acid (30.51 \%),

271 palmitic acid (24.31\%), linoleic acid (10.41\%), palmitoleic acid (7.99\%), eicosadienoic acid

272 (4.01\%), oleic acid (4.34\%) and $\alpha$-linolenic acid (3.49\%) (Table 3).

\section{Discussion}

274 Anti-diabetic properties of sage have been shown in in vitro as well as in in vivo studies. 275 However, all previous studies using diabetic animal models have been performed in 276 streptozotocin or alloxan mice or rats (Alarcon-Aguilar et al., 2002; Eidi et al., 2005; Eidi \&

277 Eidi, 2009). Both streptozotocin and alloxan induce $\beta$-cell death through alkylation of DNA by

278 the nitrosourea moiety of these compounds. For this reason, the previous animal models of 279 diabetes are more representative of type 1 diabetes (T1D) than type 2 diabetes (T2D). Type 2 280 diabetes is more common in older male population and associated with persistent low grade 281 inflammation related to adipose tissue expansion (Griffin et al., 2016; Pirola \& Candido Ferraz, 282 2017). Hence, HFD-induced obesity in 15 to 16 weeks old male mice presents an excellent model of the pre-T2D state, since the prevalence of T2D is greatly increased in obesity. The 284 present study investigated the effect of sage extract on lipolysis and lipogenesis in murine preadipocytes (3T3-L1), as well as the protective properties of low and high doses of the plant extract on inflammation, obesity and insulin resistance in a HFD animal model. 3T3-L1 cells; however sage-treated animals had a decrease in plasma NEFA and triglycerides

levels, suggesting an inhibition of lipolysis. This may be because 3T3-L1 cells differ from 
290 primary adipocytes, or because in vivo there are influences of sage on other tissues that indirectly

291 lower plasma NEFA or triglyceride levels. In sage treated mice, the plant extract improves

292 insulin sensitivity, this improvement may be partly due to a direct effect on adipose tissue and

293 thereby it may enhances the anti-lipolytic effect of insulin, resulting in a decrease in plasma

294 NEFA levels. Furthermore, lipolysis in adipose tissue is modulated in vivo by various factors

295 such as insulin, glucagon, epinephrine, norepinephrine, ghrelin, growth hormone, testosterone,

296 and cortisol, which is not the case in vitro.

297 In addition, the plant extract reduced lipid droplets accumulation in a concentration-

298 response manner when the cells were treated during both the differentiation and nutrition steps.

299 Obesity is a pathological disorder characterized by excessive fat storage endogenously; and here

300 we demonstrate that sage MetOH extract exhibited significant in vitro inhibition of lipid droplets

301 accumulation in mature adipocytes. However, sage extract was more efficient on reducing lipid

302 storage when it was added to both differentiation and nutrition media (Fig. 1D) instead to

303 differentiation or nutrition medium alone (Figs. 1B and 1C). Further analysis of the upregulation

304 or downregulation of genes such as CCAAT/enhancer binding protein- $\alpha(\mathrm{C} / \mathrm{EBP}-\alpha)$ and

305 peroxisome proliferator-activated receptor gamma (PPAR- $\gamma$ ), involved in the differentiation of

306 pre-adipocytes into fully mature adipocytes, will indicate which mechanisms sage employs in

307 decreasing lipogenesis.

308 The efficacy of $S$. officinalis in the prevention of lipid accumulation within 3T3-L1

309 adipocytes is consistent with it reducing bodyweight gain (related to adipose tissue hypertrophy)

310 in HFD mice treated with low dose sage MetOH extract. Nevertheless, this anti-obesity effect of

311 sage might be due also to reduced food intake (Table 2). 
313 an improvement of glucose tolerance, and a reduction of plasma insulin levels in response to

314 glucose load. After 3 weeks of treatment, the HOMA-IR index reflecting insulin resistance was

315 significantly decreased in sage treated-animal. The results confirm an improvement in tissue

316 insulin sensitivity. This result is in contrast with those of Eidi \& Eidi, (2009), who reported that

317 after two weeks sage ethanol extract significantly decreased serum glucose, whereas it increased

318 serum insulin levels in treated induced diabetic rats by STZ as compared with control diabetic

319 rats, and those of Alarcon-Aguilar et al. (2002) who demonstrated that the water ethanol extract

320 of sage showed hypoglycemic activity in both normo-glycemic and in mildly alloxan-diabetic

321 mice, but required the presence of insulin to exhibit its activity. On the other hand, Eidi et al.

322 (2005) reported same results as our study, showing that intraperitoneal administration sage

323 MetOH extract significantly decreased blood glucose in fasted STZ-diabetic rats without

324 increasing insulin release.

325 Our evidence from blood glucose and plasma insulin levels that low dose sage improved

326 insulin sensitivity was confirmed by an insulin tolerance test conducted after 4 weeks of

327 treatment. Thus, mice treated with sage low dose exhibited a significant decrease in blood

328 glucose levels in response to intraperitoneal insulin injection. This test, to the best of our

329 knowledge, was performed on sage-treated mice for the first time and confirms an insulin-

330 sensitizer effect of sage extract. Moreover the chronic treatment with low sage dose resulted in a

331 significant decrease in fed plasma insulin levels. A similar effect was observed in the 332 rosiglitazone-treated mice.

Sage, at low dose (100 mg.kg-1/day), has shown a better beneficial effects on glucose

tolerance, insulin sensitivity, bodyweight gain and food intake, when compared with high dose 
335 (400 mg.kg-1/day). This might be explained by an increased daily intake in palmitic acid (PA).

336 According to the content in PA of sage MetOH extract (Table 3), the daily intake of PA, in high

337 dose sage treated mice was $277 \mu \mathrm{g} . \mathrm{kg}^{-1}$, compared to $69.2 \mu \mathrm{g} \cdot \mathrm{kg}^{-1}$ in low dose treated group.

338 High levels of PA lead to insulin resistance (Reynoso et al., 2003).

339 Indeed, saturated fatty acids are major contributors to this process, as they directly impair

340 insulin sensitivity in adipocytes and muscle cells in culture through pro-inflammatory effect-

341 induced insulin resistance (Bilan et al., 2009). Moreover, in human study, Stevenson et al. (2015)

342 have reported that PUFAs rich diet consumption resulted in a decrease in ghrelin and an increase

343 in peptide YY plasma levels, when compared to SFAs rich diet. This might explain the beneficial

344 effect on food intake of sage low dose when compared to high dose. Nevertheless, it is

345 reasonable to explain the absence of the beneficial effects of high dose by a possible presence of

346 compounds that could be toxic at high levels. However, Eidi et al. (2005) have used higher dose

347 (500 mg/kg/day) and no toxic effect has been observed. Moreover, Alves Rodrigues et al. (2012),

348 have investigated in mice the toxicological effects of the hydroalcoholic extract from Salvia

349 officinalis leaves. In the acute toxicity test, the LD50 value was close to $45 \mathrm{~g} / \mathrm{kg}$, which is over

350 than 110 fold when compared to the high dose (400 mg/kg/day) used in our study. The HPLC

351 profile (Table 4 in supplemental files) of sage methanol extract showed that sage contains 13

352 compounds with almost no presence of toxic compounds. We have also conducted a preliminary

353 study on dose-response of methanol sage extract on 3T3-L1 cell proliferation and cell viability

354 (using methylene blue assay), no toxic effect has been observed.

355 This finding suggests that sage MetOH extract might act more efficiently at low doses, on

356 bodyweight gain and insulin resistance. Further studies using lower doses at 50, 25 and 10 
357 mg.kg-1 are needed to select the most effective dose. Adding palmitic acid to the dose extract

358 should also be taking into consideration to see whether it prevents the beneficial effect.

Alves Rodrigues et al. (2012), showed that oral administration of the hydroalcoholic

360

361

362

363

364

365

366

367

368

369

370

371

372

373

374

375

376

377

378

379

extract and active compounds isolated from sage, such as carnosol, oleanolic and ursolic acids reduced the nociception and oedema induced by different chemical stimuli. A study showed that S. officinalis may be used just as an adjuvant in anti-inflammatory therapy (Oniga et al., 2007). Anti-inflammatory activity of sage essential oil assessed in vitro showed that it significantly inhibited nitric oxide production elicited by LPS in macrophages (Abu-Darwish et al., 2013). Our study evaluated, for the first time, sage MetOH leaf extract effect on plasma inflammatory cytokines in HFD animals. Sage increased significantly the plasma levels of anti-inflammatory cytokines (IL-2, IL-4 and IL-10) and exhibited an opposite effect on pro-inflammatory cytokines by decreasing the plasma levels of TNF- $\alpha, \mathrm{KC} / \mathrm{GRO}$ and IL-12. KC/GRO is highly induced by pro-inflammatory cytokines such as TNF- $\alpha$ (Son et al., 2007) and the fact that plasma levels of TNF- $\alpha$ were decreased $(p=0.030)$ suggests that sage extract modulates cytokines gene expression by down regulating TNF- $\alpha$ expression and indirectly inhibiting KC/GRO release. The beneficial ant-inflammatory effects of sage methanol extract might be related to the high levels of phenolic compounds (Table 4), particularly in Rosmarinic acid (Jin et al., 2017). Nevertheless, a study on the expression of IL-10, IL-4, TNF- $\alpha$ and $\mathrm{KC} / \mathrm{GRO}$ in white adipose tissue is needed to confirm the mechanism of action.

PUFAs prevent diet-induced insulin resistance in rodents (Storlien et al., 1987). Indeed, various FAs serve as natural ligands for the three subtypes of PPARs: $\alpha, \gamma$ and $\delta$ (Christensen et al., 2009). PPAR $\alpha$ and $\gamma$ agonists modulate important metabolic events and they are the targets of drugs or candidate drugs that are effective in the treatment of metabolic disorders such as 
380 T2D, atherosclerosis (Berger et al., 2005) and obesity (Bassaganya-Riera et al., 2011). Natural

381 PPARs have fewer adverse effects than novel synthetic PPARs ligands that are suspected to

382 promote carcinogenesis in rodents by as yet, unknown mechanisms (Berger et al., 2005).

383 Nevertheless, other studies have reported an antitumor effects of the PPAR- $\gamma$ agonists

384 thiazolidinediones (TZDs), in vivo (Chaffer et al., 2006), as well as in vitro (Xu et al., 2003).

385 These anti-proliferative effects of TZDs, including cell cycle arrest and/or increased apoptosis, 386 are PPAR- $\gamma$-pathways dependent in some cancer cell types, while in other tumor cells, they occur 387 independently.

GC analysis showed that sage MetOH extract had a high content in PUFAs (48.4\%),

389

390

391

392

393

394

395

396

397

398

399

particularly in $\gamma$-linolenic acid, linoleic acid, and $\alpha$-linolenic acids. PPAR- $\gamma$ is effectively activated by PUFAs, such as linolenic acid (Dubuquoy et al., 2002). Indeed, $\gamma$-linolenic and $\alpha$ linolenic acids alone account for $34 \%$ of sage FAs content in MetOH extract and both of them are PPAR- $\alpha$ and $\gamma$ agonists (Christensen et al., 2010; Xu et al., 1999). Furthermore, several studies reported that the PUFA linoleic acid can function as ligands for both PPAR- $\alpha$ and PPAR$\gamma$ (Kliewer et al., 1997).

Our finding revealed the presence of both PPAR $\alpha$ and $\gamma$ agonists in MetOH sage extract and support previous studies which demonstrated that dichloromethane (DCM) and Ethanol $(\mathrm{EtOH})$ sage extracts contains PPARs agonists such as $\alpha$-linolenic acid, $\gamma$-linolenic acid, carnosic acid, oleanolic acid, ursolic acid and carnasol (Christensen et al., 2010; Lim et al., 2007; Rau et al., 2006).

\section{Conclusions}


401 Sage $\mathrm{MetOH}$ extract shows an anti-adipogenic effect by in vitro inhibition of lipid droplets

402 accumulation in adipocytes. In a nutritional model obesity associated with insulin resistance,

403 sage $\mathrm{MetOH}$ extract reduces bodyweight gain by a decrease in total fat mass and exhibits anti-

404 diabetic properties by an improvement of glucose tolerance and insulin sensitivity. Sage MetOH

405 extract moderately improves lipid profile, also reduces the plasma levels of the pro-inflammatory

406 cytokines TNF- $\alpha, \mathrm{KC} / \mathrm{GRO}$ and IL-12, and increases the anti-inflammatory cytokines IL-2, IL-4

407 and IL-10. Our results suggest that decreased adipose tissue associated with improved insulin 408 sensitivity and modulation of inflammatory cytokines release, balance the abnormal glucose 409 metabolism observed in pre-diabetic state.

\section{Acknowledgments}

411 The authors dedicate this work to the memory of Professor Michael A. Cawthorne 412 previous director of Buckingham Institute for Translational Medicine, who passed away in July 4132015.

\section{References}

415

416

417

418

419

420
Abu-Darwish MS, Cabral C, Ferreira IV, Gonçalves MJ, Cavaleiro C, Cruz MT, Al-bdour

TH, Salgueiro L. 2013. Essential oil of common sage (Salvia officinalis L.) from jordan: assessment of safety in mammalian cells and its antifungal and anti-inflammatory potential. Biomed Research International.1-9 DOI 10.1155/2013/538940.

Alarcon-Aguilar FJ, Roman-Ramos R, Flores-Saenz JL, Aguirre-Garcia F. 2002. Investigation on the hypoglycaemic effects of extracts of four Mexican medicinal plants 
421

422

423

424

425

426

427

428

429

430

431

432

433

434

435

436

437

438

439

440

441

in normal and alloxan-diabetic mice. Phytotherapy Research 16:383-386 DOI $10.1002 /$ ptr.914.

Alves Rodrigues MR, Kanazawaa LKS, Das Nevesa TLM, Da Silva CF, Horst H, Baggioa CH, de Paula Wernera MF. 2012. Antinociceptive and anti-inflammatory potential of extract and isolated compounds from the leaves of Salvia officinalis in mice. Journal of Ethnopharmacology 139:519-526 DOI 10.1016/j.jep.2011.11.042.

Arch J, Hislop D, Wang S, Speakman J. 2006. Some mathematical and technical issues in the measurement and interpretation of open-circuit indirect calorimetry in small animals. International Journal of Obesity 30:1322-1331 DOI 10.1038/sj.ijo.0803280.

Baricevic D, Bartol T. 2000. The biological/pharmacological activity of the Salvia genus. In: Kintzios SE, (Eds.), SAGE The Genus Salvia. Harwood Academic Publishers, Amsterdam. p. 143-184.

Bassaganya-Riera J, Guri AJ, Hontecillas R. 2011. Treatment of obesity-related complications with novel classes of naturally occurring PPAR agonists. Journal of Obesity DOI $10.1155 / 2011 / 897894$.

Bilan PJ, Samokhvalov V, Koshkina A, Schertzer JD, Samaan MC, Klip A. 2009. Direct and macrophage-mediated actions of fatty acids causing insulin resistance in muscle cells. Archives of Physiology and Biochemistry 115:176-190 DOI $10.1080 / 13813450903079314$.

Berger JP, Akiyama TE, Meinke PT. 2005. PPARs: therapeutic targets for metabolic disease. Trends in Pharmacological Sciences 26:244-251 DOI 10.1016/j.tips.2005.03.003. 
442 Bourgou S, Ksouri R, Bellila A, Skandrani I, Falleh H, Marzouk B. 2008. Phenolic

443

444

445

446

447

448

449

450

451

452

453

454

455

456

457

458

459

460

461

462

composition and biological activities of Tunisian Nigella sativa L. shoots and roots. Comptes Rendus Biologies 331:48-55 DOI 10.1016/j.crvi.2007.11.001.

Chaffer CL, Thomas DM, Thompson EW, Williams ED. 2006. PPAR $\gamma$-independent induction of growth arrest and apoptosis in prostate and bladder carcinoma. BMC Cancer 6:53-65 DOI 10.1186/1471-2407-6-53.

Christensen KB, Jørgensen M, Kotowska D, Petersen RK, Kristiansen K, Christensen LP. 2010. Activation of the nuclear receptor PPAR $\gamma$ by metabolites isolated from sage (Salvia officinalis L.). Journal of Ethnopharmacology 132:127-133 DOI 10.1016/j.jep.2010.07.054.

Christensen KB, Minet A, Svenstrup H, Grevsen K, Zhang H, Schrader E, Rimbach G, Wein S, Wolffram S, Christensen LP. 2009. Identification of plant extracts with potential antidiabetic properties: effect on human peroxisome proliferator-activated receptor (PPAR), adipocyte differentiation and insulin stimulated glucose uptake. Phytotherapy Research 23:1316-1325 DOI 10.1002/ptr.2782.

Deng B, Sullivan MA, Chen C, Li J, Powell PO, Hu Z, Gilbert RG. 2016. Molecular Structure of Human-Liver Glycogen. PLoS ONE 11 DOI 10.1371/journal.pone.0150540.

Dubuquoy L, Dharancy S, Nutten S, Pettersson S, Auwerx J, Desreumaux P. 2002. Role of peroxisome proliferator-activated receptor gamma and retinoid $\mathrm{X}$ receptor heterodimer in hepatogastroenterological diseases. Lancet $\mathbf{3 6 0}: 1410-1418$ DOI $\quad 10.1016 / \mathrm{S} 0140$ 6736(02)11395-X. 
463 Eidi A, Eidi M. 2009. Antidiabetic effects of sage (Salvia officinalis L.) leaves in normal and

464

465

466

467

468

469

470

471

472

473

474

475

476

477

478

479

480

481

482

483

484 streptozotocin-induced diabetic rats. Diabetes and metabolic syndrome: Clinical Research and Reviews 3:40-44 DOI 10.1016/j.dsx.2008.10.007.

Eidi M, Eidi A, Zamanizadeh H. 2005. Effect of Salvia officinalis L. leaves on serum glucose and insulin in healthy and streptozotocin-induced diabetic rats. Journal of Ethnopharmacology 100:310-313 DOI 10.1016/j.jep.2005.03.008.

Folch J, Lees M, Sloane Stanley GH. 1957. A simple method for the isolation and purification of total lipids from animal tissues. Journal of Biological Chemistry 226:497-509 PMID 13428781.

Griffin C, Lanzetta N, Eter L, Singer K. 2016. Sexually dimorphic myeloid inflammatory and metabolic responses to diet-induced obesity. American Journal of Physiology, Regulatory, Integrative and Comp Physiology. 311: R211-R216 DOI 10.1152/ajpregu.00136.2016

Hamidpour M, Hamidpour R, Hamidpour S, Shahlar M. 2014. Chemistry, pharmacology, and medicinal property of sage (Salvia) to prevent and cure illnesses such as obesity, diabetes, depression, dementia, lupus, autism, heart disease, and cancer. Journal of Traditional and Complementary Medicine 4:82-88 DOI 10.4103/2225-4110.130373.

Harzallah A, Hammami M, Kępczyńska MA, Hislop DC, Arch JR, Cawthorne MA, Zaibi MS. 2016. Comparison of potential preventive effects of pomegranate flower, peel and seed oil on insulin resistance and inflammation in high-fat and high-sucrose diet-induced obesity mice model. Archives of Physiology and Biochemistry 122:75-87 DOI 10.3109/13813455.2016.1148053. 
485 Jensen TL, Kiersgaard MK, Sørensen DB, Mikkelsen LF. 2013. Fasting of mice: a review. 486 Laboratory Animals 47:225-40 DOI 10.1177/0023677213501659.

487

488

489

490

491

492

493

494

495

496

497

498

499

500

501

502

503

504

505

506

507

Jin BR, Chung KS, Cheon SY, Lee M, Hwang S, Noh S, Noh-Hwang S, Rhee KJ, An HJ. 2017. Rosmarinic acid suppresses colonic inflammation in dextran sulphate sodium

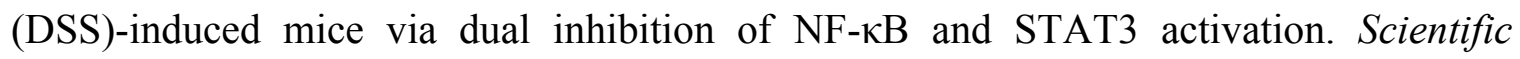
Reports 7: 46252 DOI 10.1038/srep46252.

Kliewer SA, Sundseth SS, Jones SA, Brown PJ, Wisely GB, Koble CS, Devchand P, Wahli W, Lehmann.JM. 1997. Fatty acids and eicosanoids regulate gene expression through direct interactions with peroxisome proliferator-activated receptors $\alpha$ and $\gamma$. Proceedings of the National Academy of Sciences of the United States of America. 94:4318-4323 PMCID PMC20720.

Lim SW, Hong SP, Jeong SW, Kim B, Bak H, Ryoo HC, Lee SH, Ahn SK. 2007. Simultaneous effect of ursolic acid and oleanolic acid on epidermal permeability barrier function and epidermal keratinocyte differentiation via peroxisome proliferator-activated receptor-alpha. The Journal of Dermatology 34:625-634 DOI 10.1111/j.13468138.2007.00344.x.

Lima CF, Azevedo MF, Araujo R, Fernandes-Ferreira M, Pereira-Wilson C. 2006. Metformin-like effect of Salvia officinalis (common sage): is it useful in diabetes prevention?. British Journal of Nutrition 96:326-333 DOI 10.1079/BJN20061832.

Mhamdi B, Aidi Wannes W, Sriti J, Jellali I, Ksouri R, Marzouk B. 2009. Effect of harvesting time on phenolic compounds and antiradical scavenging activity of Borago officinalis seed extracts. Industrial Crops and Products 31:1-4 DOI 10.1016/j.indcrop.2009.07.002. 
508 Oniga I, Parvu AE, Toiu A, Benedec D. 2007. Effects of Salvia officinalis L. extract on

509

510

511

512

513

514

515

516

517

518

519

520

521

522

523

524

525

526

527

528

529

530

experimental acute inflammation. Revista Medico-Chirurgicala a Societatii De Medici Si Naturalisti 111:290-294 PMID 17595884.

Pirola L and Candido Ferraz J. 2017. Role of pro- and anti-inflammatory phenomena in the physiopathology of type 2 diabetes and obesity. World Journal of Biological Chemistry 8:120-128 DOI 10.4331/wjbc.v8.i2.120.

Ramírez-Zacarías JL, Castro-Muñozledo F, Kuri-Harcuch W. 1992. Quantitation of adipose conversion and triglycerides by staining intracytoplasmic lipids with Oil red O. Histochemistry 97:493-497 DOI 10.1007/BF00316069.

Rau O, Wurglics M, Paulke A, Zitzkowski J, Meindl N, Bock A, Dingermann T, AbdelTawab M, Schubert-Zsilavecz M. 2006. Carnosic acid and carnosol, phenolic diterpene compounds of the labiate herbs rosemary and sage, are activators of the human peroxisome proliferator-activated receptor gamma. Planta Medica 72:881-887 DOI 10.1055/s-2006-946680.

Reynoso R, Salgado LM, Calderón V. 2003. High levels of palmitic acid lead to insulin resistance due to changes in the level of phosphorylation of the insulin receptor and insulin receptor substrate-1. Molecular and Cellular Biochemistry 246:155-162 DOI 10.1007/978-1-4615-0298-2_22.

Shahneh FZ, Valiyari S, Baradaran B, Abdolalizadeh J, Bandehagh A, Azadmehr A, Hajiaghaee R. 2013. Inhibitory and cytotoxic activities of Salvia officinalis L. extract on human lymphoma and leukemia cells by induction of apoptosis. Advanced Pharmaceutical Bulletin 3:51-55 DOI 10.5681/apb.2013.009. 
531 Son DS, Parl AK, Montgomery Rice V, Khabele D. 2007. Keratinocyte chemoattractant

$532(\mathrm{KC}) /$ human growth regulated oncogene $(\mathrm{GRO})$ chemokines and proinflammatory 533 chemokine networks in mouse and human ovarian epithelial cancer cells. Cancer Biology $534 \quad$ and Therapy 6:1302-1312 DOI 10.4161/cbt.6.8.4506.

535 Stevenson JL, Clevenger HC, Cooper JA. 2015. Hunger and satiety response to high-fat meals of varying fatty acid composition in women with obesity. Obesity 23:1980-1986 DOI 10.1002/oby.21202.

538

539

540

541

542

543

544

545

546

547

548

549

550

551

552

Stocker CJ, Wargent E, O'Dowd J, Cornick C, Speakman JR, Arch JR, Cawthorne MA. 2007. Prevention of diet-induced obesity and impaired glucose tolerance in rats following administration of leptin to their mothers. American Journal of Physiology-Regulatory, Integrative and Comparative Physiology 292:1810-1818

DOI 10.1152/ajpregu.00676.2006.

Storlien LH, Kraegen EW, Chisholm DJ, Ford GL, Pascoe WS. 1987. Fish oil prevents insulin resistance induced by high-fat feeding in rats. Science 237:885-888 URL: http://www.jstor.org/stable/1699894.

Xu HE, Lambert MH, Montana VG, Parks DJ, Blanchard SG, Brown PJ, Sternbach DD, Lehmann JM, Wisely GB. 1999. Molecular recognition of fatty acids by peroxisome proliferator-activated receptors. Molecular Cell 3:397-403 DOI 10.1016/S1097-2765(00)80467-0.

Xu Y, Iyengar S, Roberts RL, Shappell SB, Peehl DM. 2003. Primary culture model of peroxisome proliferator-activated receptor gamma activity in prostate cancer cells. J Cell Physio 196:131-43 DOI 10.1002/jcp.10281. 


\section{Table $\mathbf{1}$ (on next page)}

Composition of the Rodent Diet with $60 \%$ kcal\%fat.

The high fat diet was formulated by E. A. Ulman, Ph.D. (Research Diets, Inc. 20 Jules Lane New Brunswick, NJ 08901 USA). The respective fat percentages in saturated, monounsaturated and polyunsaturated fatty acids are $37.1 \%, 46 \%$ and $16.9 \%$. 
1 Table 1

2

Product \#

High fat diet D12492

\begin{tabular}{|c|c|c|}
\hline & gm\% & kcal\% \\
\hline Protein & 26.2 & 20 \\
\hline Carbohydrate & 26.3 & 20 \\
\hline Fat & 34.9 & 60 \\
\hline Total & & 100 \\
\hline kcal/gm & 5.24 & \\
\hline Ingredient & gm & kcal \\
\hline Casein, 80 Mesh & 200 & 800 \\
\hline L-Cysine & 3 & 12 \\
\hline Corn Starch & 0 & 0 \\
\hline Maltodextrin 10 & 125 & 500 \\
\hline Sucrose & 63.8 & 275.2 \\
\hline Cellulose, BW200 & 50 & 0 \\
\hline Soybean Oil & 25 & 225 \\
\hline Lard & 245 & 2205 \\
\hline Mineral Mix, S10026 & 10 & 0 \\
\hline DiCalcium Phosphate & 13 & 0 \\
\hline Calcium Carbonate & 5.5 & 0 \\
\hline Potassium Citrate, $1 \mathrm{H} 2 \mathrm{O}$ & 16.5 & 0 \\
\hline Vitamin Mix, V10001 & 10 & 40 \\
\hline Choline Bitartrate & 2 & 0 \\
\hline FD\&C Blue Dye \#1 & 0.05 & 0 \\
\hline Total & 773.85 & 4057 \\
\hline
\end{tabular}




\section{Table 2 (on next page)}

Cumulative food intake, bodyweight change, lean and fat massat day 32 of treatment.

Lean and fat mass were measured by Nuclear Magnetic Resonance (NMR). ${ }^{*} p<0.05$ as compared to group $A$; data are expressed in mean $\pm S E M$; $(n=7$ in group $A$ and $n=8$ in groups $B, C$ and $D)$. 


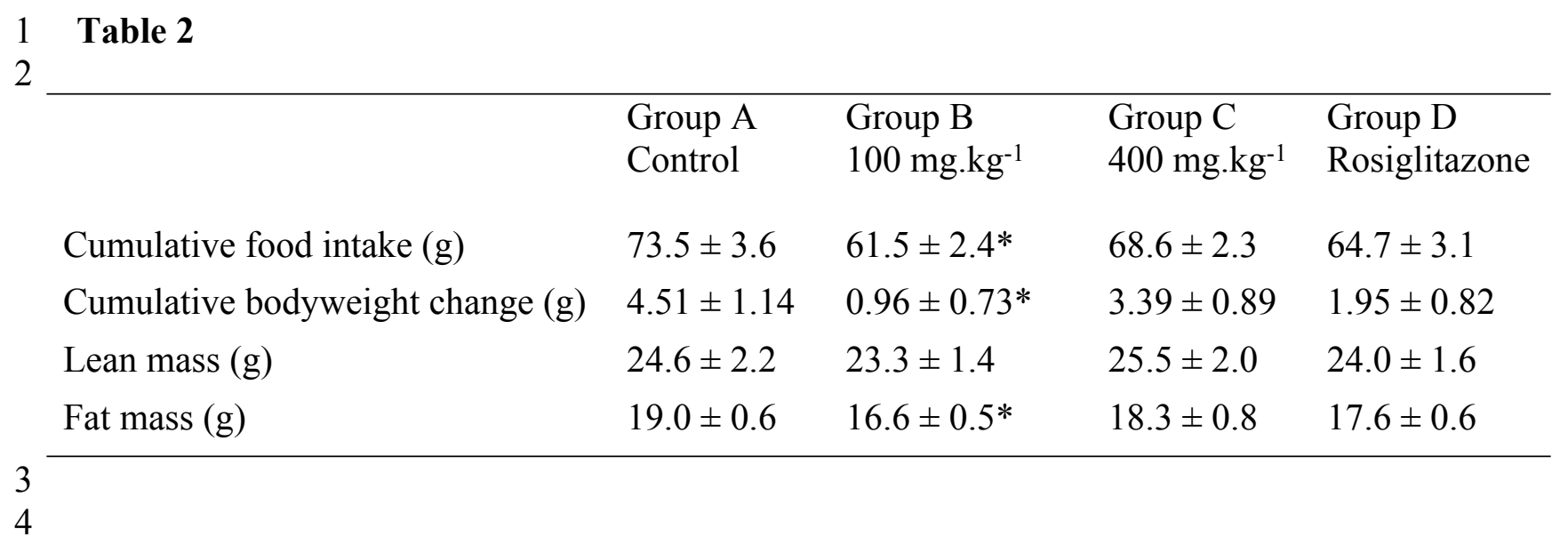




\section{Table 3(on next page)}

Fatty acids (FAs) composition of sage Methanol extract,measured by Gas Chromatography (GC).

FAs were analysed by GC in the following conditions: Injector and Flame lonization Detector (FID) temperature were set at $250^{\circ} \mathrm{C}$ and $280^{\circ} \mathrm{C}$, respectively. Oven temperature was kept at $150^{\circ} \mathrm{C}$ for $1 \mathrm{~min}$ then gradually raised to $230^{\circ} \mathrm{C}$ at $10^{\circ} \mathrm{C} / \mathrm{min}$ and subsequently, held isothermal for $10 \mathrm{~min}$. Nitrogen was the carrier gas at a split ratio of 1:50, a linear velocity of $38.5 \mathrm{~cm} / \mathrm{sec}$ and a flow rate of $1.2 \mathrm{ml} / \mathrm{min}$. 
1

2

3

4

Table 3

\begin{tabular}{|c|c|c|c|c|}
\hline & Nomenclature & Name & $\begin{array}{l}\text { Content } \\
(\mu \mathrm{g} / \mathrm{g})\end{array}$ & $\begin{array}{l}\text { Percentage } \\
\%\end{array}$ \\
\hline \multirow{9}{*}{$\begin{array}{l}\text { Saturated fatty } \\
\text { acids (SFAs) }\end{array}$} & $\mathrm{C} 4: 0$ & Butyric acid & 27.99 & 0.98 \\
\hline & C6:0 & Caproic acid & 28.11 & 0.99 \\
\hline & $\mathrm{C} 10: 0$ & Citric acid & 26.94 & 0.95 \\
\hline & $\mathrm{C} 12: 0$ & Lauric acid & 35.14 & 1.23 \\
\hline & $\mathrm{C} 14: 0$ & Myristic acid & 44.27 & 1.55 \\
\hline & $\mathrm{C} 16: 0$ & Palmitic acid & 692.34 & 24.32 \\
\hline & C18:0 & Stearic acid & 127.67 & 4.48 \\
\hline & $\mathrm{C} 20: 0$ & Arachidic acid & 71.30 & 2.50 \\
\hline & $\mathrm{C} 24: 0$ & Lignoceric acid & 32.40 & 1.14 \\
\hline \multirow{6}{*}{$\begin{array}{l}\text { Monounsaturated } \\
\text { fatty acids } \\
\text { (MUFAs) }\end{array}$} & $\mathrm{C} 16: 1 \omega-7$ & Palmitoleic acid & 227.71 & 8.00 \\
\hline & $\mathrm{C} 18: 1 \omega-9$ & Oleic acid & 123.70 & 4.34 \\
\hline & $\mathrm{C} 18: 1 \omega-7$ & Vaccenic Acid & 22.89 & 0.80 \\
\hline & $\mathrm{C} 20: 1 \omega-9$ & Gadoleic acid & 7.36 & 0.26 \\
\hline & C22 $1 \omega-9$ & Erucic acid & 0.2 & 0.01 \\
\hline & $\mathrm{C} 24: 1 \omega-9$ & Nervonic acid & 0.12 & $<0.01$ \\
\hline \multirow{4}{*}{$\begin{array}{l}\text { Polyunsaturated } \\
\text { fatty acids } \\
\text { (PUFAs) }\end{array}$} & $\mathrm{C} 18: 2 \omega-6$ & Linoleic acid & 296.40 & 10.41 \\
\hline & $\mathrm{C} 18: 3 \omega-6$ & $\gamma$-linolenic acid & 868.69 & 30.51 \\
\hline & $\mathrm{C} 18: 3 \omega-3$ & $\alpha$-linolenic acid & 99.48 & 3.49 \\
\hline & $\mathrm{C} 20: 2 \omega-6$ & Eicosadienoic acid & 114.29 & 4.01 \\
\hline
\end{tabular}

6

7

8 


\section{Table 4(on next page)}

Phenolic compounds content of $S$. officinalis methanol extract.

The phenolic compounds separation was performed using a Hewlett-Packard liquid chromatographic system. The identification and quantification of compounds was carried out by comparison of their retention times and pics area, with respect to pure standards analyzed under the same operating conditions. Values are given as mean \pm standard error of three replicate analyses. ( ${ }^{a}$ Retention time. ${ }^{b}$ Dry weight). 


\section{Table 4}

2

\begin{tabular}{|c|c|c|c|}
\hline & Phenolic compounds & $\mathbf{R}_{\mathrm{T}}^{\mathrm{a}}(\min )$ & Content (mg/Kg of DW) \\
\hline & Phenolic acid & & \\
\hline 1 & Gallic acid & 5.029 & $11.08 \pm 1.2$ \\
\hline 2 & 4-OH Benzoic acid & 7.559 & $9.95 \pm 1.3$ \\
\hline 3 & Rosmarinic acid & 12.458 & $290.73 \pm 8.4$ \\
\hline \multirow[t]{2}{*}{4} & Cinnamic acid & 17.138 & $17.13 \pm 2.6$ \\
\hline & Flavones & & \\
\hline 5 & Luteolin-7-O-glucoside & 9.230 & $10.89 \pm 1.7$ \\
\hline 6 & Apigenin-7-O-glucoside & 10.616 & $10.80 \pm 1.8$ \\
\hline \multirow[t]{2}{*}{7} & Apigenin & 16.700 & $18.50 \pm 2.2$ \\
\hline & Flavonols & & \\
\hline 8 & Rutin & 8.429 & $10.15 \pm 1.5$ \\
\hline \multirow[t]{2}{*}{9} & Quercetin & 15.101 & $2.26 \pm 0.4$ \\
\hline & Stilbenes & & \\
\hline \multirow[t]{2}{*}{10} & Resveratrol & 15.411 & $7.15 \pm 1.2$ \\
\hline & Catechins & & \\
\hline \multirow[t]{2}{*}{11} & Catechin Hydrate & 6.278 & $6.75 \pm 0.9$ \\
\hline & Phenylethanoid glycoside & & \\
\hline \multirow[t]{2}{*}{12} & Verbascoside & 8.806 & $17.47 \pm 1.6$ \\
\hline & Lignans & & \\
\hline 13 & Pinoresinol & 15.782 & $1.84 \pm 0.3$ \\
\hline
\end{tabular}


Figure 1

Effects of Salvia officinalis methanol (sage MetOH) extract on lipolysis and lipogenesis in 3T3-L1 cells

Levels of glycerol released in the culture medium of fully differentiated adipocytes after being incubated for 90 min with or without $0.2,1,5,25$ and $50 \mu \mathrm{g} / \mathrm{ml}$ of methanol sage extract (A) . Lipid droplets accumulation measured in 3T3-L1 cells treated with different sage extract concentrations during the stage of

differentiation (B), nutrition (C), or both (D). All values are mean \pm SEM ( $n=4$, in each treated cell group). Statistical analysis were performed using one way anova test followed by Dunnett's multiple comparison test. $* p<0.05 ; * * * p<0.001$.

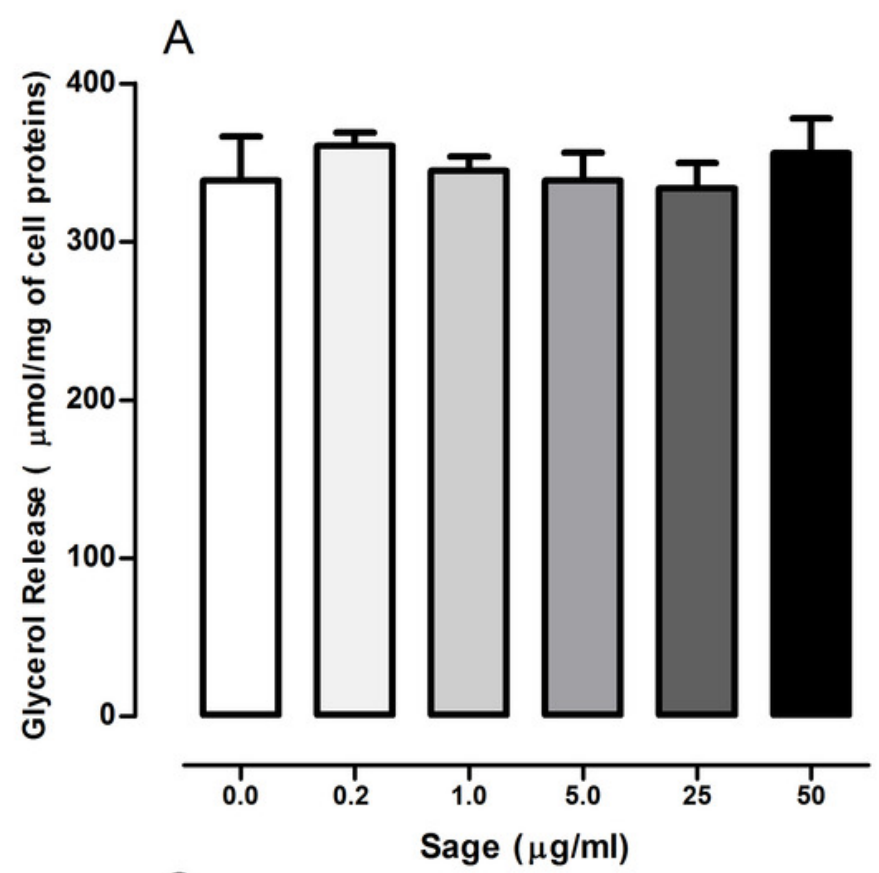

C
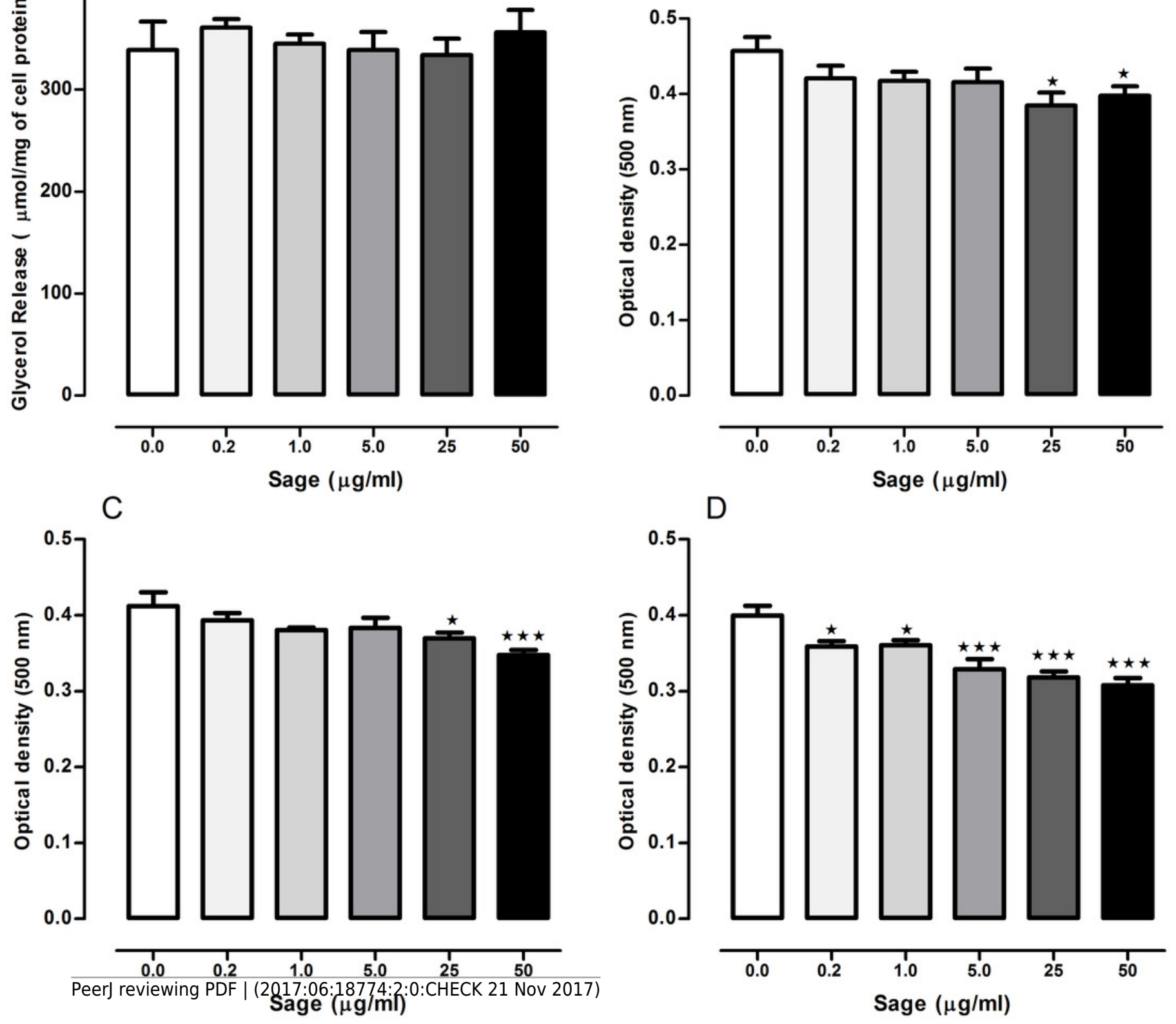


\section{Figure 2}

Oral glucose tolerance test $(\mathrm{A})$ and plasma insulin levels 30 min before and after glucose load (B)

HFD mice were treated for 2 weeks with sage MetOH extract (100 mg/kg/day and $400 \mathrm{mg} / \mathrm{kg} /$ day), and rosiglitazone ( $3 \mathrm{mg} / \mathrm{kg} / \mathrm{day})$. Glucose solution $(2.5 \mathrm{~g} / \mathrm{kg})$ was given orally after 5 hours fast. Blood glucose values represent mean + SEM ( $n=7$ in group $A$ and $n=8$ in groups $B, C$ and $D)$, and statistical significance compared with the vehicle group data is shown as: $* P<0.05$, ** $P<0.01$ and $* * * P<0.001$. 


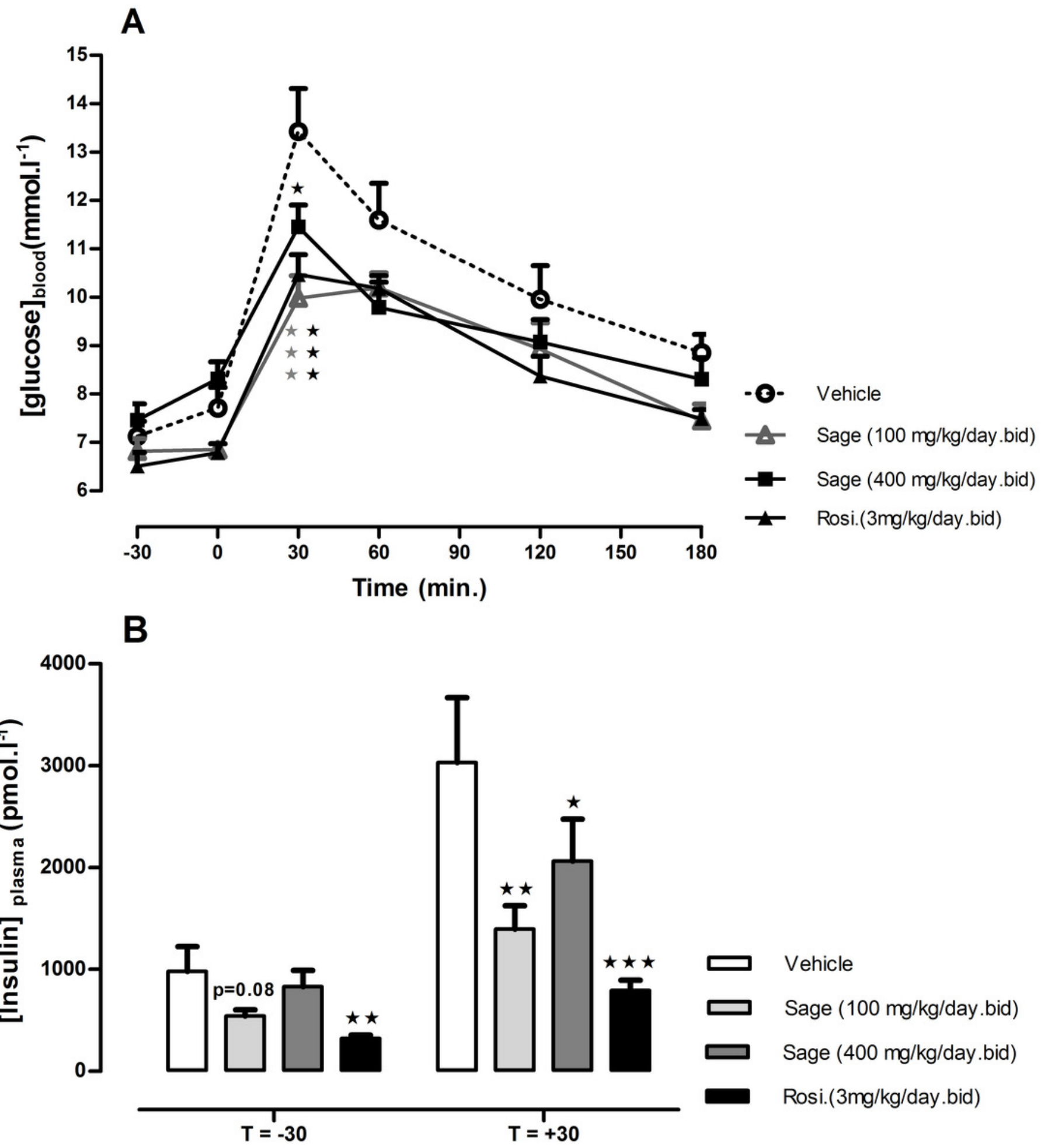




\section{Figure 3}

\section{Effects of Salvia officinalis MetOH extract on fasted blood glucose, and insulin sensitivity}

Blood glucose levels were measured after a 5 -hour fast (A), and insulin sensitivity is represented by the product of blood glucose and plasma insulin values (B), after 3 weeks of treatment with sage MetOH extract (100 mg/kg/day and $400 \mathrm{mg} / \mathrm{kg} / \mathrm{day})$, and rosiglitazone ( $3 \mathrm{mg} / \mathrm{kg} /$ day). Blood glucose levels were observed during the Insulin tolerance test (C), performed at day 29 of treatment. Insulin (Actrapid, $0.75 \mathrm{UI} / \mathrm{kg} / \mathrm{ml}$ in saline) was injected intraperitoneally to 5 -hour fasted mice. All values are means \pm SEM ( $n=7$ in group $A$ and $\mathrm{n}=8$ in groups $\mathrm{B}, \mathrm{C}$ and $\mathrm{D})$. $* \mathrm{P}<0.05, * * \mathrm{P}<0.01$ and $* * * P<0.001$ as compared to the vehicle-treated group. 

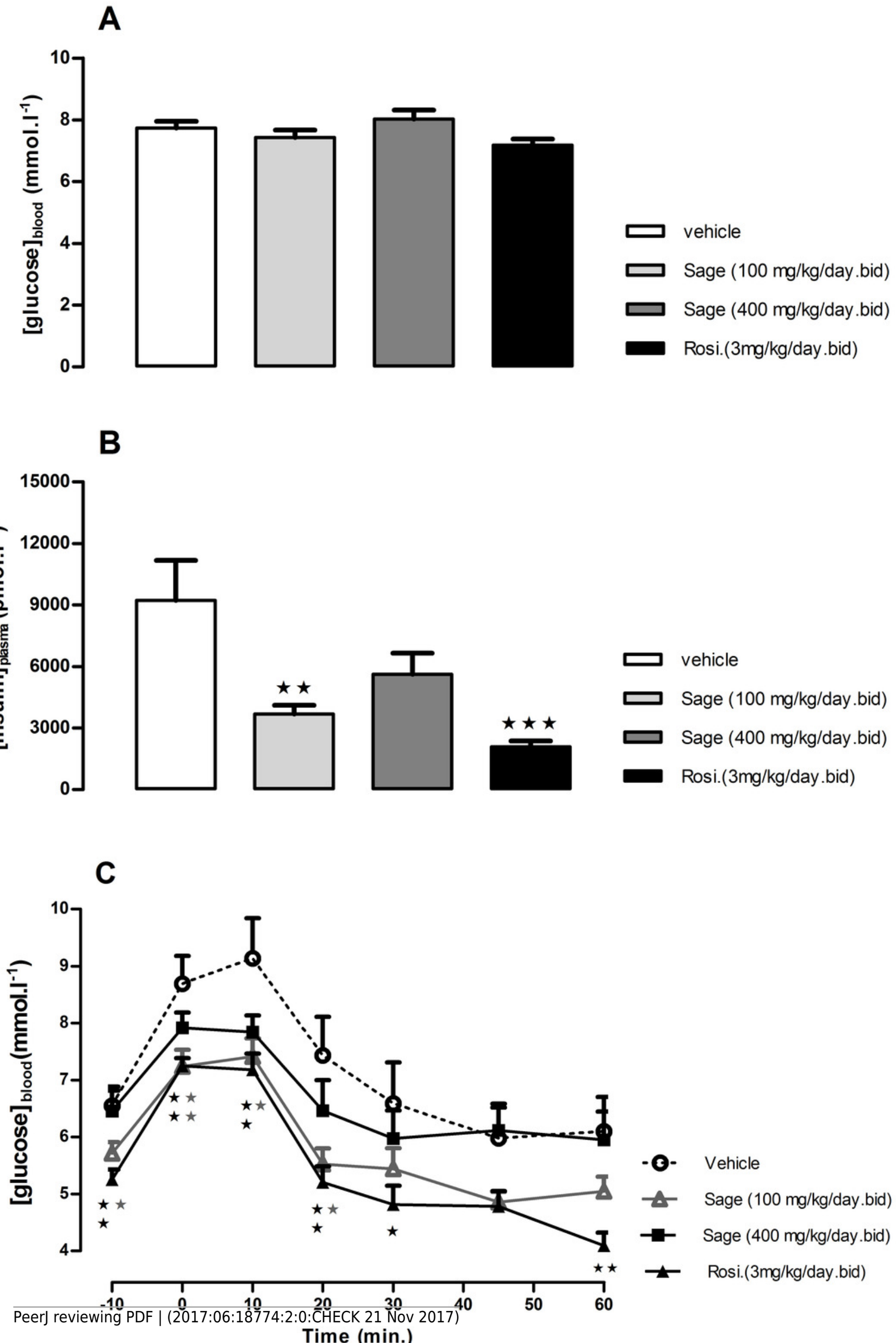


\section{Figure 4}

Plasma levels of insulin (A) , leptin (B) ,total cholesterol (C), HDL-Cholesterol (D) , Triglycerides $(E)$, and NEFA (F), after 5 weeks of treatment with sage MetOH extract .

The plasma samples were collected from fed mice, at the termination day, after 5 weeks treatment with sage MetOH extract (100 mg/kg/day and $400 \mathrm{mg} / \mathrm{kg} /$ day), and rosiglitazone $(3 \mathrm{mg} / \mathrm{kg} /$ day). Values represent mean + SEM ( $n=7$ in group $A$ and $n=8$ in groups $B, C$ and $D)$, and statistical significance compared with the vehicle group data is shown as: $* P<0.05$ and $* * P<0.01$.
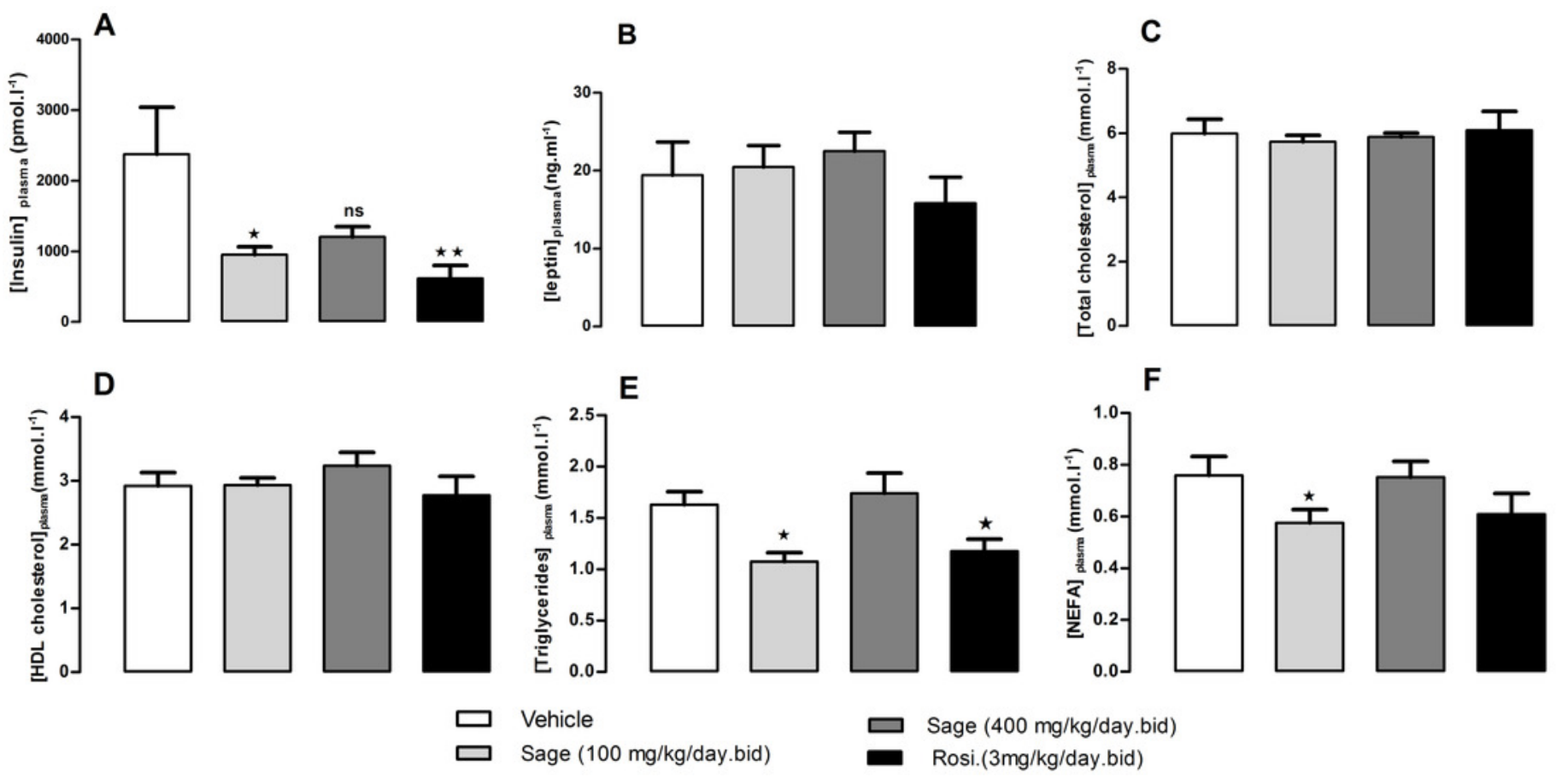


\section{Figure 5}

Plasma levels of 'anti- and pro- inflammatory' cytokines after chronic treatment with low dose of sage MetOH extract

Comparison between the levels of anti-inflammatory $(A)$, and pro-inflammatory cytokines (B), measured in plasma samples collected from fed mice treated for 5 weeks with sage extract low dose sage MetOH extract (100 mg/kg/day), and mice control group (water: $10 \mathrm{ml} / \mathrm{kg} /$ day). Values represent mean $+\mathrm{SEM}$ ( $\mathrm{n}=7 \mathrm{in}$ group $A$ and $n=8$ in group $B$ ), and statistical significance compared with the vehicle group data is shown as: $* P<0.05$ and $* * P<0.01$. 


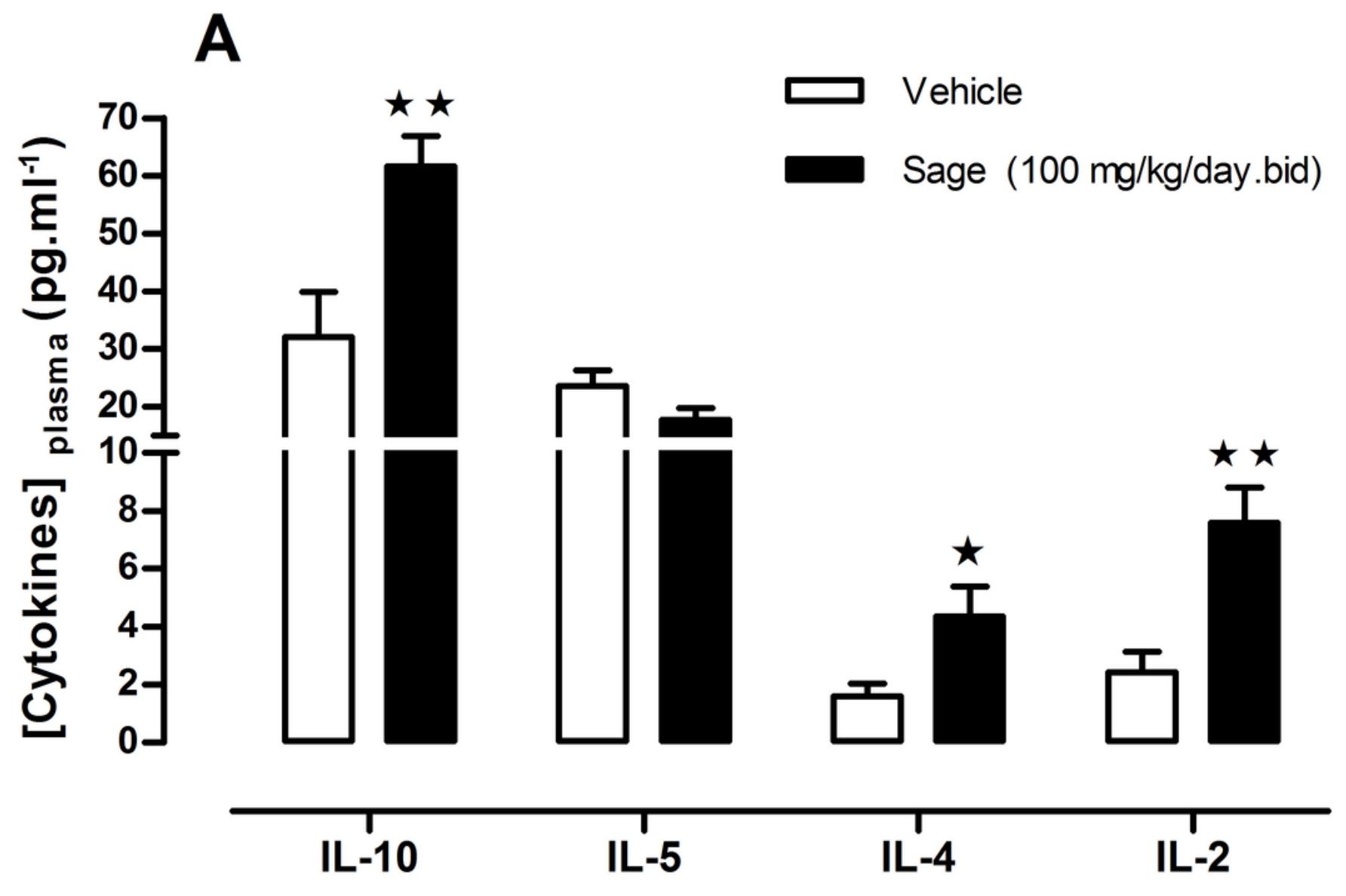

B
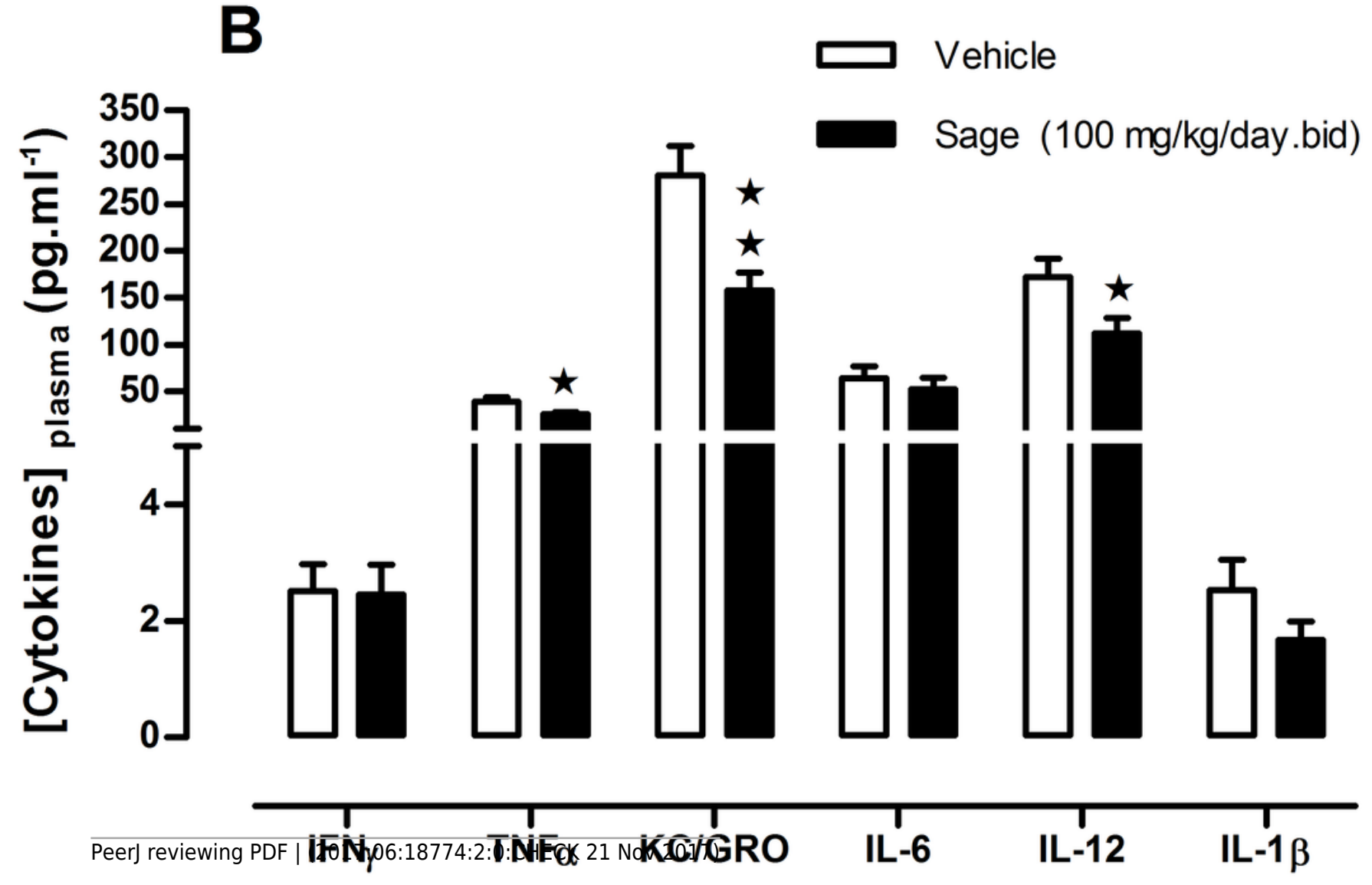
Figure 6

Sage fatty acids profile analysed by Gas Chromatography (GC).

Typical chromatogram of sage fatty acid profile analyzed by GC. The composition of fatty acid in sage MetOH extract contains different classes ranging from C4:0 to C24:0. FA methyl esters (FAMEs) were identified by comparing each sample with a standard FAME reference mixture, and FA acid peak areas were calculated using HP ChemStation software

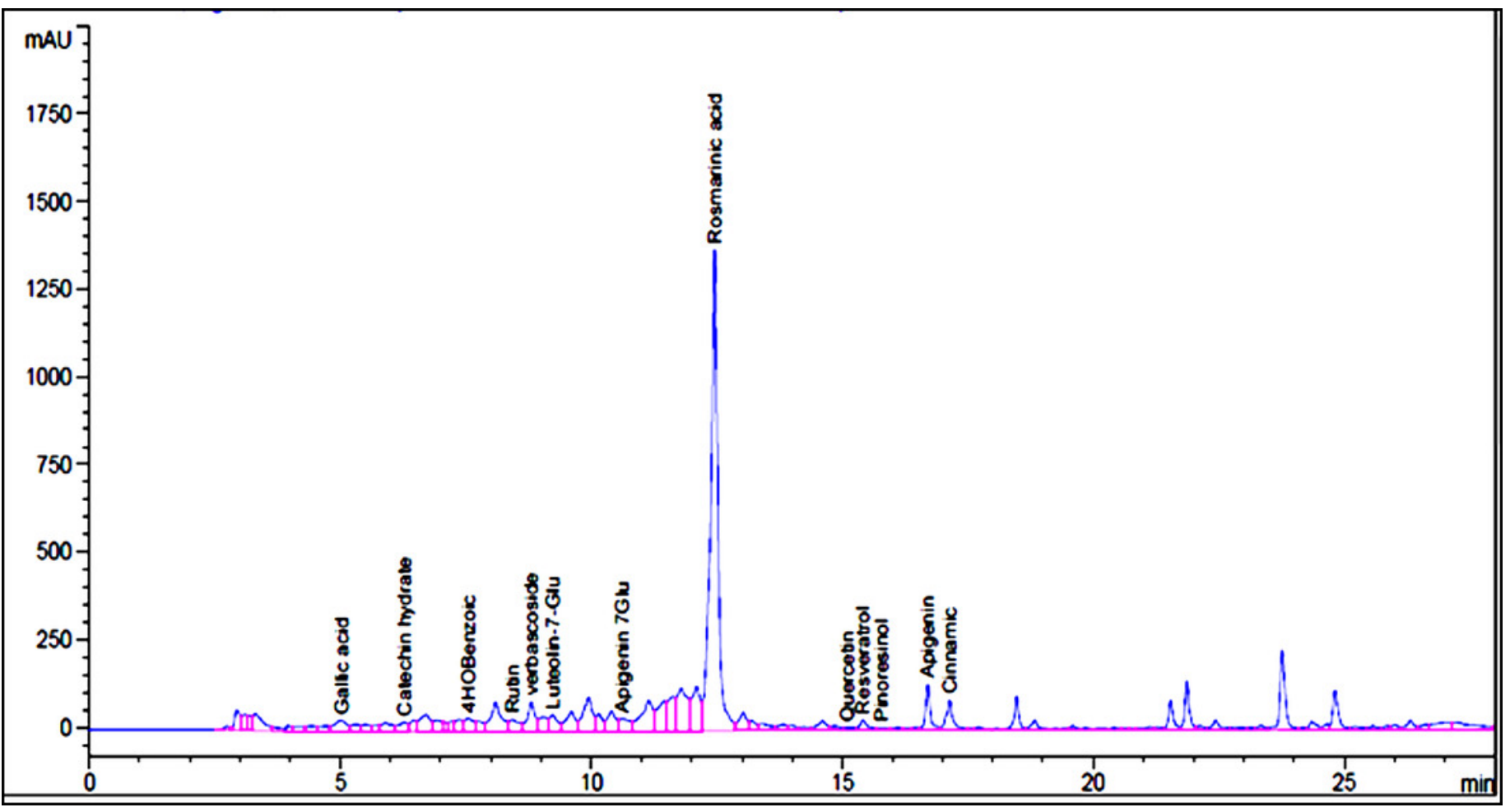

